\title{
CONTENTS OF VOLUME 43
}

KOKOU Y. ABALO and MICHAEL M. KOSTREVA: Existence theory for games of pricing and technology

THOMAS M. ACHO and DOMINIC P. CLEMENCE: The parameter dependent SturmLiouville eigenproblem with an interior simple or double pole

D. D. BAINOV and I. M. STAMOVA: Stability of the solutions of impulsive functionaldifferential equations by Lyapunov's direct method

D. D. BAINOV, A. B. DISHLIEV and I. M. STAMOVA: Practical stability of the solutions of impulsive systems of differential-difference equations via the method of comparison and some applications to population dynamics

E. BALAKRISHNAN: See M. I. NELSON

E. BALAKRISHNAN: See R. O. WEBER

R. BALL: See A. C. MCINTOSH

SHAUN R. BELWARD and LAWRENCE K. FORBES: A simple model for oilspill containment

J. BRINDLEY, J. F. GRIFFITHS, A. C. MCINTOSH and J. ZHANG: Initiation of combustion waves in solids, and the effects of geometry

QIANSHUN CHANG: See LIMING MA

$X$. D. CHEN: See M. I. NELSON

XIAO DONG CHEN: Self-heating behaviour of low moisture content particles-modelling the basket-heating of solid particles and some aspects of the cross over behaviour using milk powder as an example

DOMINIC P. CLEMENCE: See THOMAS M. ACHO

S. CROZIER: See C. J. SNAPE-JENKINSON

K. P. DAS: See SUMA DEBSARMA

SUMA DEBSARMA and K. P. DAS: Fourth order nonlinear evolution equations for gravitycapillary waves in the presence of a thin thermocline in deep water

JAMES P. DENIER: See JILLIAN A. K. STOTT

W. DERRICK: See R. O. WEBER

WILLIAM DERRICK: See LAWRENCE K. FORBES

A. B. DISHLIEV: See D. D. BAINOV

J. DROZD: See S. SAUJANI

LAWRENCE K. FORBES and WILLIAM DERRICK: A combustion wave of permanent form in a compressible gas

LAWRENCE K. FORBES: See SHAUN R. BELWARD

L. K. FORBES: See C. J. SNAPE-JENKINSON

J. GRAHAM-EAGLE and D. A. SCHULT: Combustion waves with reactant depletion

B. F. GRAY: On the critical conditions for an assembly of interacting thermons

B. F. GRAY: See C. MACASKILL

B. F. GRAY: See A. C. MCINTOSH 
B. F. GRAY: See R. O. WEBER

J. F. GRIFFITHS: See J. BRINDLEY

BAO ZHU GUO: Further results for a one-dimensional linear thermoelastic equation with Dirichlet-Dirichlet boundary conditions

XIANPING GUO and WEIPING ZHU: Denumerable state continuous time Markov decision processes with unbounded cost and transition rates under average criterion

ISHAK HASHIM: On competition between modes at the onset of Bénard-Marangoni convection in a layer of fluid

V. IVANCEVIC and C. E. M. PEARCE: Topological duality in humanoid robot dynamics

L. S. JENNINGS: See K. L. TEO

Y. KANG and J.-M. VANDEN-BROECK: Stern waves with vorticity

A. A. KILBAS: See R. K. RAINA

SANGJEONG KIM: Gevrey class regularity of the magnetohydrodynamics equations

MICHAEL M. KOSTREVA: See KOKOU Y. ABALO

YANG KUANG: Global stability and persistence in diffusive food chains

W. R. LEE: See K. L. TEO

B. LIU: See T. R. MARCHANT

XINZHI LIU, S. SIVALOGANATHAN and SHENGHAI ZHANG: Analysis of cell population PDE models with general maturation rates

Y. LIU: See K. L. TEO

LIMING MA and QIANSHUN CHANG: Multigrid methods for the biharmonic equation using some nonconforming plate elements

C. MACASKILL, M. J. SEXTON and B. F. GRAY: A reaction-diffusion model of stored bagasse

A. C. MCINTOSH, B. F. GRAY, G. C. WAKE and R. BALL: The stability of a near-adiabatic Endex batch CSTR reactor

A. C. MCINTOSH: See J. BRINDLEY

R. MALLIER: See S. SAUJANI

T. R. MARCHANT and B. LIU: On the heating of a two-dimensional slab in a microwave cavity: aperture effects

M. MATIC, C. E. M. PEARCE and J. PEČARIĆ: Some refinements of Shannon's inequalities

G. N. MERCER: See M. I. NELSON

G. N. MERCER: See R. O. WEBER

M. I. NELSON, H. S. SIDHU, R. O. WEBER and G. N. MERCER: A dynamical systems model of the limiting oxygen index test

M. I. NELSON, G. C. WAKE, X. D. CHEN and E. BALAKRISHNAN: The multiplicity of steady-state solutions arising from microwave heating. I. Infinite Biot number and small penetration depth

C. E. M. PEARCE: See V. IVANCEVIC

C. E. M. PEARCE: See M. MATIĆ

J. PEČCARIĆ: See M. MATIĆ

R. K. RAINA, H. M. SRIVASTAVA, A. A. KILBAS and M. SAIGO: Solvability of some Abel-type integral equations involving the Gauss hypergeometric function as kernels in the spaces of summable functions 
M. SAIGO: See R. K. RAINA

S. SAUJANI, J. DROZD and R. MALLIER: Nonlinear evolution of singular disturbances to a $\tanh ^{3} y$ mixing layer

D. A. SCHULT: See J. GRAHAM-EAGLE

M. J. SEXTON: See C. MACASKILL

H. S. SIDHU: See M. I. NELSON

H. S. SIDHU: See R. O. WEBER

S. SIVALOGANATHAN: See XINZHI LIU

WILLIAM V. SMITH: Wave motion in a conducting fluid with a layer adjacent to the boundary, II. Eigenfunction expansions

C. J. SNAPE-JENKINSON, S. CROZIER and L. K. FORBES: NMR shim coil design utilising a rapid spherical harmonic calculation method

MIODRAG M. SPALEVIĆ: Calculation of Chakalov-Popoviciu quadratures of Radau and Lobatto type

H. M. SRIVASTAVA and YEONG-NAN YEH: Certain theorems on bilinear and bilateral generating functions

H. M. SRIVASTAVA: See R. K. RAINA

I. M. STAMOVA: See D. D. BAINOV

STEVO STEVIĆ: Growth theorems for homogeneous second-order difference equations

JILLIAN A. K. STOTT and JAMES P. DENIER: The stability of boundary layers on curved heated plates

K. L. TEO, W. R. LEE, L. S. JENNINGS, S. WANG and Y. LIU: Numerical solution of an optimal control problem with variable time points in the objective function

J.-M. VANDEN-BROECK: See Y. KANG

G. C. WAKE: See A. C. MCINTOSH

G. C. WAKE: See M. I. NELSON

G. C. WAKE: See R. O. WEBER

S. WANG: See K. L. TEO

R. O. WEBER, G. C. WAKE, H. S. SIDHU, G. N. MERCER, B. F. GRAY, W. DERRICK and E. BALAKRISHNAN: On the crossing of intermediate unstable steady state solutions for thermal ignition in a sphere

R. O. WEBER: See M. I. NELSON

YEONG-NAN YEH: See H. M. SRIVASTAVA

J. ZHANG: See J. BRINDLEY

SHENGHAI ZHANG: See XINZHI LIU

WEIPING ZHU: See XIANPING GUO 